\title{
Effect of starter cultures and packaging methods on amino acid profile and eating quality characteristics of pork ham
}

\author{
Protiva Gogoi • R. N. Borpuzari • T. Borpuzari • \\ R. A Hazarika • J. R Bora
}

Revised: 16 August 2014 / Accepted: 25 August 2014 / Published online: 25 September 2014

(C) Association of Food Scientists \& Technologists (India) 2014

\begin{abstract}
Wet cured pork hams were inoculated with a mixed starter cultures comprising of Lactobacillus acidophilus and Micrococcus varians M483 at the dose level of $106 \mathrm{cfu} / \mathrm{g}$ and the un inoculated hams served as controls. The amino acid profile of hams of the treated and the control groups stored at $4 \mathrm{oC}$ under MAP and VP and evaluated on 60th day of storage revealed that treated hams liberated higher concentration of free amino acids except for proline and methionine which were found in higher concentration $(P<0.01)$ in the MAP control samples. The MAP control samples liberated glutamic acid $(85.65 \pm 1.40 \mathrm{ppm})$, cystine $(21.56 \pm 1.14 \mathrm{ppm})$ and tyrosine $(16.63 \pm 1.94 \mathrm{ppm})$ whereas, the treated samples did not release these amino acids. The VP control samples too liberated cystine $(6.98 \pm 1.36 \mathrm{ppm})$ and arginine $(42.70 \pm 2.78 \mathrm{ppm})$ but the treated ham of the VP did not liberate these amino acids. The VP hams had higher concentration $(P<0.01)$ of free proline, glycine, alanine, valine, methionine, isoleucine, phenylalanine, lysine and histidine than the MAP samples. Colour analysis of ham using CIE Lab colour system revealed that the treated samples had significantly higher concentrations of $\mathrm{L}^{*}$, $a^{*}$ and $b^{*}$ components. The $L^{*}$ and $a^{*}$ values were higher in the MAP than under VP systems while the $b^{*}$ values were higher in the VP samples than the MAP samples. Neither the
\end{abstract}

P. Gogoi $\cdot$ R. N. Borpuzari $(\bowtie) \cdot$ T. Borpuzari

AICRP on Post Harvest Technology, Department of Livestock

Products Technology, College of Veterinary Science, Assam

Agricultural University, Khanapara, Guwahati 781 022, India

e-mail: borpuzarirn@yahoo.com

\section{R. A. Hazarika}

Department of Veterinary Public Health, College of Veterinary

Science, Assam Agricultural University, Khanapara, Guwahati 781

022, India

\section{J. R. Bora}

Department of Livestock Production and Management, College of Veterinary Science, Assam Agricultural University, Khanapara, Guwahati 781 022, India bacterial cultures nor the packaging system influenced the textural property of ham. Starter cultures inoculated hams were rated superior $(P<0.05)$ in terms of their sensory properties. Hams packaged under MAP were rated superior $(P<0.05)$ than those packaged under VP in terms of appearance, colour, taste, tenderness, flavour, juiciness and overall acceptability.

Keywords Ham · Starter cultures · Vacuum packaging · Modified atmosphere $\cdot$ Packaging $\cdot$ Free amino acid

Use of starter cultures in ham processing brings desirable biochemical changes resulting in improvement in sensory properties by flavour development and texture softening. Mild proteolysis and lipolysis of the added cultures, the curing ingredients and the endogenous enzymes cause appreciable improvement in the organoleptic qualities of the fermented meat products. In order to improve sensory quality and good colour formation, lactic acid bacteria alone are not sufficient and the contribution of nitrate/nitrite reducing organisms becomes essential. Typical starter cultures for cured ham production comprise of LAB to lower the $\mathrm{pH}$, together with nitrite/ nitrate reducing Micrococcaceae to aid in colour development. During the process of ripening, protein breakdown reactions yield peptides and free amino acids which participate in the development of typical taste of the fermented meat products and also act as precursors of volatile compounds. However, Montel et al. (1992) observed that several species of Lactobacillus and Pediococcus used as starter cultures played no role in protein hydrolysis but opined that the peptidasic activities of LAB could contribute to the increased level of FAA.

In order to extend the storage life, vacuum (VP) or modified atmosphere packaging (MAP) are being increasingly applied for ham distribution and retail sale (Stiles 1990). MAP has become more common and has successfully been applied to different raw and processed meat products 
(Ahvenainen et al. 1990; Pexara et al. 2002). $\mathrm{CO}_{2}$ has been reported to be extensively used in raw and cooked cured products because of its strong inhibitory effect against microorganisms (Borch et al. 1996; Sørheim et al. 2004). However, the shelf life of MAP meat products as compared to their VP counterparts was found to be poor in some studies (Pexara et al. 2002 and Santos et al. 2005).

The objectives of this study were to investigate the effects of starter cultures comprising of $L$. acidophilus and Micrococcus varians ${ }_{\mathrm{M} 483}$ with proven nitrite/ nitrate reducing properties (Borpuzari and Boschkova 1993) and packaging methods (VP and MAP) on the amino acid profile and eating quality characteristics of pork ham.

\section{Materials and methods}

Hams weighing 5-6 kg were fabricated from healthy pigs slaughtered at the slaughterhouse of the NAIP (Component2) sub-project by separating the hind leg at the point of hip joint. A long deep incision was given on the medial aspect of the ham and the aitch bone was removed out.

Curing of ham The deboned hams were then pumped with the brine with the help of a multi-needle brine injector (Model: PI 11, Gunther Machinenbau, Germany) 5 times by keeping the skin side down. Approximately, 750 to $900 \mathrm{ml}$ (not exceeding $15 \% \mathrm{v} / \mathrm{w}$ of the ham) of the brine solution was injected per ham (Common salt@ @ \% , Brown sugar@1\%, Sodium nitrite@ $0.025 \%$, Sodium tripolyphosphate @ $0.5 \%$, Sodium ascorbate @ $0.1 \%$ and Liquid smoke @ 1\%). After injecting the brine, hams were vacuum tumbled at $100 \mathrm{kPa}$ of vacuum pressure for an hour in a vacuum tumbler (Model: LU 2×25, Lumar Ideal II, Inc, Canada) for uniform distribution of the brine.

Application of starter cultures Meat starter cultures comprising of L. acidophilus and M. varians ${ }_{\mathrm{M}} 483$ were obtained from the culture collection of the AICRP on PHT laboratory. These strains were originally isolated from a raw-dried fermented sausage. Slant cultures of $L$. acidophilus were transferred to MRS broth (deMann et al. 1960) and that of M. varians ${ }_{\text {M483 }}$ to Mannitol salt broth (Chapman 1945) and incubated at $37^{\circ} \mathrm{C}$ for 18-20 hour. Active cultures were then pelleted by centrifuging at $5000 \mathrm{rpm}$ for $10 \mathrm{~min}$ in a refrigerated centrifuge (Model: 3 K30, Sigma, Germany). The pellets were resuspended in sterile physiological saline solution to the desired concentration of cells. Number of cells per millilitre was determined by direct microscopic count as described by Harrigan and McCance (1976). The mixed cultures at the ratio of 1:1 were then injected at multiple sites of the cured and tumbled ham to reach a dose level of approximately $10^{6} \mathrm{cfu} / \mathrm{g}$. Ham samples without inoculation of the starter cultures served as control.
The control and treated hams were then immersed separately in a weaker brine solution \{common salt reduced by $0.5 \%$ $(\mathrm{w} / \mathrm{v})\}$ and stored at $4{ }^{\circ} \mathrm{C}$ for 10 days. After this fermentation period, the rind and fat from the hams along with fascia were removed and kept hung in ham net bags for $15 \mathrm{~min}$. Cold smoking at $25{ }^{\circ} \mathrm{C}$ was done for an hour in a smoke cabinet (Model: 1600 RET-C, Kerres, Germany). After smoking, the hams were again stored at $12{ }^{\circ} \mathrm{C}$ for another 4 days. The hams were then cooked in the cooking vat (Model: Mera 200, Talsa, Spain) to an internal temperature of $75{ }^{\circ} \mathrm{C}$ for an hour. Cooked hams were cooled overnight at $4{ }^{\circ} \mathrm{C}$ before carving. Ham slices of both the control and treated groups were then vacuum packaged and modified atmosphere packaged in the vacuum packaging machine (Model: QS 500 MAP, Sevana, India) equipped with MAP facility. The gas mixture of $\mathrm{CO}_{2}, \mathrm{~N}_{2}$ and $\mathrm{O}_{2}$ in the MAP was in the ratio of $1: 1: 1$.

Amino acid analysis The amino acid content of the finished product (stored for 60 days at refrigeration temperature) was determined in 5 replicates by using an amino acid analyzer (Model: 850 Professional IC, Metrohm, Switzerland).

The binary gradient was performed with an 850 Professional IC Cation Gradient. A high pressure pump with backpressure column was used for smooth transportation of the PCR reagent. The PCR reaction took place at $120^{\circ} \mathrm{C}$ in the UV/VIS detector. The IC sample centre kept the samples cool during the measurement.

Reagents:

\begin{tabular}{|c|c|}
\hline Eluent $A$ & $\begin{array}{c}: \quad 42.6 \mathrm{mmol} / \mathrm{L} \text { lithiumcitrate, } 10.6 \mathrm{mmol} / \mathrm{L} \text { phenol, } \\
\mathrm{pH} 2.8(\mathrm{HCl})\end{array}$ \\
\hline Eluent B & $\begin{array}{r}\quad 42.6 \mathrm{mmol} / \mathrm{L} \text { lithiumcitrate, } 1.0 \mathrm{mmol} / \mathrm{L} \text { lithium } \\
\text { chloride, } 10.6 \mathrm{mmol} / \mathrm{L} \text { phenol, } \mathrm{pH} 4.2(\mathrm{HCl})\end{array}$ \\
\hline PCR solution & $\begin{array}{l}0.11 \mathrm{mmol} / \mathrm{L} \text { Ninhydrin }+2.5 \mathrm{mmol} / \mathrm{L} \text { Hydrindantin } \\
\text { dissolved in }(1: 1)=(\text { DMSO:2 M lithium acetate } \\
\text { at } \mathrm{pH} 5.2)\end{array}$ \\
\hline
\end{tabular}

Operating parameters:

\begin{tabular}{ll}
\hline Flow rate column & $0.4 / \mathrm{ml}$ \\
Flow rate PCR & $0.2 / \mathrm{ml}$ \\
Injection volume & Partial loop $1-40 \mu \mathrm{L}$ \\
$\mathrm{P}_{\text {max }}$ & $10.0 \mathrm{MPa}$ \\
Recording time & $95 \mathrm{~min}$ \\
Temperature column & $50{ }^{\circ} \mathrm{C}$ \\
Temperature PCR & $120{ }^{\circ} \mathrm{C}$ \\
Light source & $\mathrm{VIS}(\mathrm{W})$ \\
Measuring duration & $300 \mathrm{~ms}$ \\
Wavelength & $570 \pm 5 \mathrm{~nm}$ \\
& $440 \pm 5 \mathrm{~nm}$ (Proline) \\
Reference & $700 \pm 5 \mathrm{~nm}$
\end{tabular}


Colour characteristics The colour characteristics of the hams stored for 60 days at refrigeration temperature of both the treated and control groups packaged under different packaging systems were studied by using a spectrophotometer (Model: Cary 100 Bio UV-vis, Varian, Holland) equipped with solid sample holder and colour software at 380 to $800 \mathrm{~nm}$ in 5 replicates each.

The colour parameters were analyzed using the colour coordinates for CIE Lab. Positive values of $\mathrm{L}^{*}$ meant lighter or the brightness of the meat, whereas, the negative value indicated the darker colour or dullness in the meat sample. Positive $\mathrm{a}^{*}$ indicated the dominance of red colour in the meat and negative value was the indication of the green colour. Positive values of the $b^{*}$ indicated the yellowness of the sample whereas, the negative value indicated more blue colouration.

Shear force value The texture of the VP and MAP ham samples of the treated and the control groups was determined on 1 st, 15, 30, 45, 50, 55 and 60th day of storage under refrigeration temperature samples by using texture analyzer (Model: Texture Analyzer HD Plus, Stable Micro Systems, U.K.) equipped with Warner-Bratzler shear apparatus in five replicates each.

The ham samples were cut into cylindrical shapes using a core borer of $1.2 \mathrm{~cm}$ diameter. The operating parameters consisted of a cross-head speed of $2 \mathrm{~mm} / \mathrm{sec}$ and a $100 \mathrm{~kg}$ load cell. The shear force perpendicular to the axis of ham piece was measured for each of the samples. The peak of the shear force profile was regarded as the shear force value.

Sensory evaluation Sensory evaluation of 5 batches of the treated and control ham samples stored under MAP and VP in refrigeration temperature was done on 60th day of storage. Ham samples were cut into small pieces and warmed up by light frying and were served to a 7-membered semi trained panel and the ratings in terms of appearance, colour, taste, tenderness, flavour, juiciness and overall acceptability of the product were obtained through a 9-point hedonic score card as described by Bratzler (1971).

Statistical analysis The data collected for the various parameter of the study were analyzed statistically as per SAS Enterprise Guide 4.2 (2008).

\section{Results and discussion}

Analysis of free amino acids revealed that the treated samples liberated almost all the amino acids at higher concentration than the control samples except for proline and methionine which were found in higher concentration $(P<0.01)$ in the
MAP control samples (Table 1). The MAP control samples liberated glutamic acid (85.65 $\pm 1.40 \mathrm{ppm})$, cystine $(21.56 \pm$ $1.14 \mathrm{ppm})$ and tyrosine $(16.63 \pm 1.94 \mathrm{ppm})$ whereas, the treated samples did not release these amino acids. The VP control samples too liberated cystine $(6.98 \pm 1.36 \mathrm{ppm})$ and arginine $(42.70 \pm 2.78 \mathrm{ppm})$ but the treated ham of the VP did not liberate these amino acids. Serine and lysine were not liberated in the control samples packaged under VP and MAP

Table 1 Amino acid profile of ham under different packaging conditions (Comparison of means of groups within packaging and means of packaging within groups)

\begin{tabular}{|c|c|c|c|}
\hline \multirow[t]{2}{*}{ Amino acids } & \multirow[t]{2}{*}{ Packaging } & \multicolumn{2}{|c|}{ Concentration (ppm) } \\
\hline & & Control & Treated \\
\hline \multirow[t]{2}{*}{ Aspartic acid } & MAP & $16.19^{\mathrm{a}} \pm 1.62$ & $56.68^{\mathrm{b}} \pm 1.17$ \\
\hline & VP & - & - \\
\hline \multirow[t]{2}{*}{ Serine } & MAP & - & - \\
\hline & VP & - & $51.75 \pm 1.54$ \\
\hline \multirow[t]{2}{*}{ Glutamic acid } & MAP & $85.65^{\mathrm{A}} \pm 1.40$ & - \\
\hline & VP & $72.81^{\mathrm{aB}} \pm 1.98$ & $508.20^{\mathrm{b}} \pm 4.46$ \\
\hline \multirow[t]{2}{*}{ Proline } & MAP & $244.57^{\mathrm{aA}} \pm 2.59$ & $150.68^{\mathrm{bA}} \pm 2.60$ \\
\hline & VP & $91.69^{\mathrm{aB}} \pm 3.04$ & $160.25^{\mathrm{bB}} \pm 2.32$ \\
\hline \multirow[t]{2}{*}{ Glycine } & MAP & $31.71^{\mathrm{aA}} \pm 1.96$ & $98.76^{\mathrm{bA}} \pm 2.72$ \\
\hline & $\mathrm{VP}$ & $49.93^{\mathrm{aB}} \pm 1.87$ & $267.23^{\mathrm{bB}} \pm 2.59$ \\
\hline \multirow[t]{2}{*}{ Alanine } & MAP & $71.24^{\mathrm{aA}} \pm 2.64$ & $182.81^{\mathrm{bA}} \pm 2.13$ \\
\hline & VP & $104.58^{\mathrm{aB}} \pm 1.61$ & $802.38^{\mathrm{bB}} \pm 1.48$ \\
\hline \multirow[t]{2}{*}{ Valine } & MAP & $22.22^{\mathrm{a}} \pm 0.63$ & $28.88^{\mathrm{bA}} \pm 0.97$ \\
\hline & VP & $23.62^{\mathrm{a}} \pm 1.28$ & $237.65^{\mathrm{bB}} \pm 1.53$ \\
\hline \multirow[t]{2}{*}{ Cystine } & MAP & $21.56^{\mathrm{A}} \pm 1.14$ & - \\
\hline & VP & $6.98^{\mathrm{B}} \pm 1.36$ & - \\
\hline \multirow[t]{2}{*}{ Methionine } & MAP & $24.80^{\mathrm{aA}} \pm 1.26$ & $13.39^{\mathrm{bA}} \pm 1.20$ \\
\hline & VP & $11.60^{\mathrm{aB}} \pm 0.80$ & $94.16^{\mathrm{bB}} \pm 1.57$ \\
\hline \multirow[t]{2}{*}{ Isoleucine } & MAP & $16.22 \pm 2.16$ & $16.80^{\mathrm{A}} \pm 1.72$ \\
\hline & $\mathrm{VP}$ & - & $434.40^{\mathrm{B}} \pm 3.86$ \\
\hline \multirow[t]{2}{*}{ Leucine } & MAP & $41.83^{\mathrm{a}} \pm 2.03$ & $49.36^{\mathrm{b}} \pm 1.27$ \\
\hline & VP & $50.09 \pm 30.03$ & - \\
\hline \multirow[t]{2}{*}{ Tyrosine } & MAP & $16.63 \pm 1.94$ & - \\
\hline & VP & - & - \\
\hline \multirow[t]{2}{*}{ Phenyl alanine } & MAP & $21.75^{\mathrm{a}} \pm 1.72$ & $26.56^{\mathrm{bA}} \pm 1.01$ \\
\hline & VP & - & $283.22^{\mathrm{B}} \pm 1.91$ \\
\hline \multirow[t]{2}{*}{ Lysine } & MAP & - & $97.50^{\mathrm{A}} \pm 1.94$ \\
\hline & $\mathrm{VP}$ & - & $179.82^{\mathrm{B}} \pm 1.73$ \\
\hline \multirow[t]{2}{*}{ Histidine } & MAP & - & $15.65^{\mathrm{A}} \pm 1.58$ \\
\hline & VP & $23.82^{\mathrm{a}} \pm 1.70$ & $44.06^{\mathrm{bB}} \pm 1.82$ \\
\hline \multirow[t]{2}{*}{ Arginine } & MAP & - & $50.35 \pm 2.42$ \\
\hline & VP & $42.70 \pm 2.78$ & - \\
\hline
\end{tabular}

$N=5$, Means in a row bearing superscript (lowercase) between groups within each packaging system differ significantly $(P<0.01)$

Means in a column bearing superscript (uppercase) between packaging within each treatment group differ significantly $(P<0.01)$ 
systems. Free isoleucine concentration of the control and the treated hams packaged under MAP did not differ significantly.

The VP ham of the treated group had free serine and phenylalanine contents of $51.75 \pm 1.54$ and $283.22 \pm$ $1.91 \mathrm{ppm}$, respectively whereas their counterparts in the control group did not liberate these amino acids at all. Likewise, the MAP ham of the treated group had free histidine and arginine content of $15.65 \pm 1.58$ and $50.35 \pm 2.42 \mathrm{ppm}$ against nil content of these amino acids in the control group.

The packaging systems employed had statistically significant effect on the concentration of free amino acids of the hams of the treated group. As compared to the MAP samples, the VP samples of the treated group had significantly higher concentration $(P<0.01)$ of free proline $(160.25 \pm 2.32 \mathrm{vs}$ $150.68 \pm 2.60 \mathrm{ppm})$, glycine $(267.23 \pm 2.59$ vs $98.76 \pm$ $2.72 \mathrm{ppm})$, alanine ( $802.38 \pm 1.48$ vs $182.81 \pm 2.13 \mathrm{ppm})$, valine (237.65 \pm 1.53 vs $28.88 \pm 0.97 \mathrm{ppm})$, methionine (94.16 \pm 1.57 vs $13.39 \pm 1.20 \mathrm{ppm})$, isoleucine ( $434.40 \pm 3.86$ vs $16.80 \pm$ $1.72 \mathrm{ppm})$, phenylalanine $(283.22 \pm 1.91$ vs $26.56 \pm$ $1.01 \mathrm{ppm})$, lysine $(179.82 \pm 1.73$ vs $97.50 \pm 1.94 \mathrm{ppm})$ and histidine $(44.06 \pm 1.82$ vs $15.65 \pm 1.58 \mathrm{ppm})$.

Scannell et al. (2004) during the production of fermented non-dried whole muscle ham with proteolytic starter culture observed that there were no significant differences in individual free amino acids between the samples inoculated with proteolytic starter cultures and the control. Guo and Chen (1991) reported that the proteolytic phenomena of microbial origin have been traditionally attributed to proteases of Micrococcaceae and LAB. Hierro et al. (1999) in their study on the contribution of microbial and meat endogenous enzymes to the free amino acid and amine contents of dry fermented sausages reported increase in the FAA during storage.

Colour characteristics of ham Analysis of the colour characteristics of the control and the treated hams packaged under MAP and VP systems and stored for 60th day revealed that the $\mathrm{L}^{*}, \mathrm{a}^{*}$ and $\mathrm{b}^{*}$ values were found to be in higher concentration $(P<0.01)$ in the treated group. The MAP samples showed higher intensity of $L^{*}$ and $a^{*}$ values and lower $b^{*}$ values than the VP samples in both the treated and the control hams (Table 2).
Scannell et al. (2002) observed that the colour of the fermented ham had visibly deteriorated after 14 days of storage. Throughout the storage over 56 days, a* values decreased slightly while $\mathrm{L}^{*}$ increased in both the fermented and unfermented ham slices and $b^{*}$ values were significantly higher in the fermented ham. Kotzekidou and Bloukas (1996) reported that the sliced vacuum-packed cooked hams produced with Staph. xylosus had higher a* values than the control, indicating a redder product.

Jin et al. (2010) reported that with increased storage time, the $L^{*}$ values in dry cured pork neck showed a tendency to increase in all the three types of packaging (NP, VP and MAP). The VP samples showed higher $L^{*}$ values than the MAP samples and the redness $\left(\mathrm{a}^{*}\right)$, which is used as an indicator of colour stability in meat and meat products was lower in VP than MAP samples at 60th day of storage. As regards to yellowness $\left(b^{*}\right)$, the VP samples showed higher values than the MAP samples at the 60th day of storage.

Shear force value of ham The textural properties of the hams measured as shear force value ranged from 10.81 to $13.15 \mathrm{~g}$ in the treated ham and from 11.35 to $13.83 \mathrm{~g}$ in the control samples (Fig. 1), the difference, however, being statistically non-significant. The samples analyzed on 45th day of storage showed that the ham of the treated group packaged under VP system was significantly tenderer than the control samples. Overall, packaging did not seem to play any role on the textural characteristics of the ham in either of the control or the treated samples.

Rai et al. (2006) reported that when used as mixed culture, L. casei subspp casei-1.001 and Staph. xylosus- 12 showed the lowest values for texture profile of dry fermented Chinesestyle sausage. In agreement with the findings of the present study, Jin et al. (2010) reported that there were no significant differences in shear force value between NP, MAP, VP of dry cured pork neck during storage up to 90 days.

Sensory properties of ham The sensory evaluation of the control and the treated hams packaged under MAP and VP performed on 60th day of storage indicated that use of mixed starter cultures of L. acidophilus and M. varians ${ }_{\mathrm{M} 483}$ brought

Table 2 Effect of packaging systems on colour characteristics of ham (Comparison of means of groups within packaging)

\begin{tabular}{|c|c|c|c|c|c|c|}
\hline \multirow[t]{2}{*}{ Treatment groups } & \multicolumn{6}{|c|}{ Colour component } \\
\hline & $\begin{array}{l}\mathrm{L}^{*} \\
\text { MAP }\end{array}$ & $\begin{array}{l}a^{*} \\
V P\end{array}$ & $\begin{array}{l}b^{*} \\
\text { MAP }\end{array}$ & VP & MAP & VP \\
\hline Control & $45.91^{\mathrm{a}} \pm 0.54$ & $44.70^{\mathrm{a}} \pm 1.67$ & $8.29^{\mathrm{a}} \pm 0.58$ & $7.27^{\mathrm{a}} \pm 0.50$ & $11.18^{\mathrm{a}} \pm 0.31$ & $12.14^{\mathrm{a}} \pm 1.73$ \\
\hline Treated & $52.09^{\mathrm{b}} \pm 0.23$ & $51.61^{\mathrm{b}} \pm 1.56$ & $10.19^{\mathrm{bA}} \pm 0.41$ & $9.01^{\mathrm{bB}} \pm 0.30$ & $19.92^{\mathrm{b}} \pm 0.78$ & $22.09^{\mathrm{b}} \pm 0.99$ \\
\hline
\end{tabular}

$N=5$ Means in a column bearing uncommon superscript (lowercase) between groups within each packaging system of a colour component differ significantly $(P<0.01)$

Means in a row bearing uncommon superscript (uppercase) between packaging systems within each group of a colour component differ significantly $(P<0.05)$ 
Fig 1 Textural properties (Shear force value) of Ham (Comparison of means of packaging according to days within groups and means of groups within packaging) $N=5$ Means in a column bearing uncommon superscript between groups within packaging systems differ significantly $(P<0.05)$

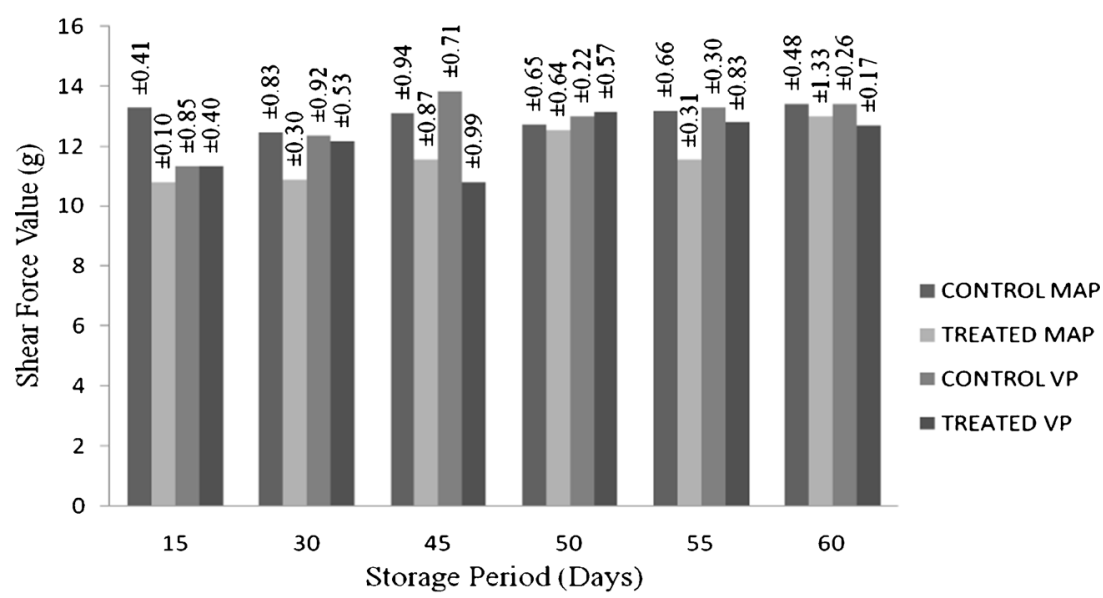

Textural Properties (Shear Force Value) of Ham about desirable changes in hams with regards to all the traits studied. Hams packaged under MAP were preferred by the panellists than those packaged under VP in either of the control or the treated groups in all the traits $(P<0.05)$ except for taste. Control sample packaged under VP was rated higher for taste $(P<0.05)$ than the MAP ham (Fig. 2). Superior panel preferences of the starter culture treated ham could be attributed to the production of carbonyl compounds, volatile fatty acids, lactic acid, diacetyl, acetoin etc. by the starter cultures that might have contributed to the taste and flavour of the finished product.

Geisen et al. (1992) reported that staphylococci and micrococci could protect the colour changes and rancidity in the meat product. Moreover, by producing lipase these could take part in breakdown of fat into flavour active breakdown products ensuring desirable flavour qualities to the product. Several researchers (Lucke 1985; Bacus 1986) have emphasized on the role of Micrococcaceae in aromatisation of fermented meat products. Scannell et al. (2002) reported that the panellists found the hams fermented with $L$. sakei and Staph. carnosus better for taste and texture profile and were more acceptable than delicatessen purchased control hams.

\section{Conclusion}

Inoculation of pork ham with bacterial starter cultures comprising of L. acidophilus and M. varians ${ }_{\mathrm{M} 483}$ and packaged under MAP and VP revealed higher evolution of free amino acids than the control samples except for proline and methionine which were found in higher concentration $(P<0.01)$ in the MAP control samples. Higher evolution of the free amino acids in the treated samples might be due to the proteases produced by the starter organisms. The VP ham of the treated group had free serine and phenylalanine contents of $51.75 \pm$ 1.54 and $283.22 \pm 1.91 \mathrm{ppm}$, respectively whereas, their counterparts in the control group did not liberate these amino acids at all. Likewise, the MAP ham of the treated group had free histidine and arginine content of $15.65 \pm 1.58$ and $50.35 \pm$ $2.42 \mathrm{ppm}$ against nil content of these amino acids in the control group.

The MAP samples showed higher intensity of $\mathrm{L}^{*}$ and $\mathrm{a}^{*}$ values and lower $b^{*}$ values than the VP samples in both the treated and the control hams. MAP better stabilized cured meat colour of ham slices than VP. Neither the bacterial starter cultures nor the packaging systems employed influenced the
Fig 2 Sensory properties of pork ham stored under vacuum and modified atmosphere packaging means $N=5$ Means in a column bearing uncommon superscript between groups within packaging systems differ significantly $(P<0.05)$.

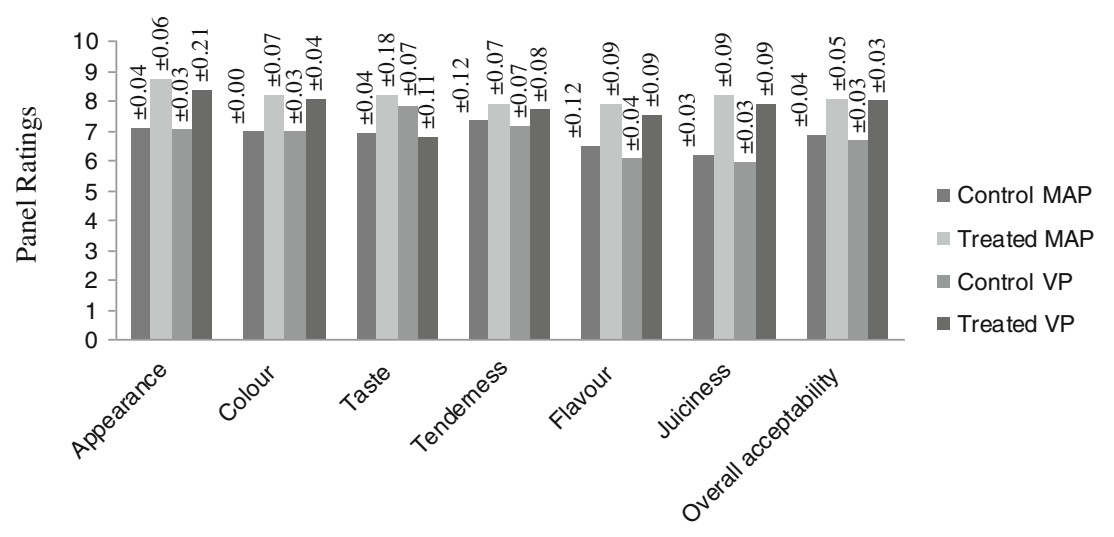

Sensory Attributes 
textural properties of pork ham. Treated hams packaged under MAP enjoyed the highest panel ratings $(P<0.05)$ for the sensory traits evaluated.

Acknowledgments The authors sincerely acknowledge the administrative support of the Assam Agricultural University, Jorhat - 785013 and the Project Coordination Unit of the All India Coordinated Research Project on Post Harvest Technology, Indian Council of Agricultural Research, Ludhiana in providing financial support to carry out the research work.

\section{References}

Ahvenainen R, Kivikataja RL, Skytta E (1990) Factors affecting shelf-life of gas and vacuum-packed cooked meat products. Part II Vienna sausages Lebensmittel-Wissenschaft und Technologie 23:130-138

Bacus J N (1986). Fermented meat and poultry products. In: Advances in Meat Res. Meat and Poultry Microbiology. (Eds. Pearson, A.M. and Dutson, T.R.) AVI Publishing, pp.123

Borch E, Kant-Muermans ML, Blixt Y (1996) Bacterial spoilage of meat and cured meat products. Int J Food Microbiol 33:103-120

Borpuzari R N, Boschkova K (1993). Isolation and characterization of Micrococcaceae from Bulgarian raw-dried sausage. In: Proc. 39th Int. Cong. Meat Sci. Technol., Calgary, Canada, File No. SP01. WP

Bratzler L J (1971). Palatability factors and evaluation. In science of meat and meat products. (Edr. Price, J. F. and Schoriewert, B. S.)

Chapman GH (1945) The significance of sodium chloride in studies of staphylococci. J Bacteriol 50:201

deMann JC, Rogosa ME, Sharpe ME (1960) A medium for the cultivation of lactobacilli. J Appl Bacteriol 23:130

Geisen R, Lucke FK, Krockel L (1992) Starters and protective cultures for meat and meat products. Fleischwirt 72:894

Guo SL, Chen MT (1991) Studies on the microbial flora of Chinese-style sausage. 1. The microbial flora and its biochemical characteristics. Fleischwirtschaft 71:1425-1426
Harrigan WF, McCance ME (1976) Laboratory methods in food and dairy microbiology. Acad. Press, London

Hierro E, Hoz L, Ordonez J (1999) Contribution of the microbial and meat endogenous enzymes to the free amino acid and amine contents of dry fermented sausages. J Agric Food Chem 47:1156-1161

Jin SK, Mandal PK, Kim IS, Kang SN (2010) Effects of packaging methods and refrigerated storage on the quality of dry-cured pork neck. Asian J Anim Vet Adv 5:526-536

Kotzekidou P, Bloukas JG (1996) Effect of protective cultures and packaging film permeability on shelf-life of sliced vacuum-packed cooked ham. Meat Sci 42:333-345

Lucke K (1985) Fermented sausages. In: Wood BJ (ed) Microbiology of fermented foods. Elsevier, London

Montel MC, Talon R, Cantonnet M, Cayrol J (1992) Peptidasic activities of starter cultures. Proc Int Congr Meat Sci Technol ClermontFerrand 38:811-813

Pexara ES, Metaxopoulos J, Drosinos EH (2002) Evaluation of shelf life of cured, cooked, sliced turkey fillets and cooked pork sausages "piroski" - stored under vacuum and modified atmospheres at +4 and +10 C. Meat Sci 62:33-43

Rai KP, Zhang C, Xia W (2006) The effects of mixed starter cultures on the quality of dry fermented Chinese-style sausages. Tropical Agric Res Extension 9:103-115

Santos EM, Jaime I, Rovira J, Lyhs U, Korkeala H, Bj rkroth J (2005) Characterization and identification of lactic acid bacteria in "morcilla de Burgos". Int J Food Microbiol 97:285-296

SAS Enterprise Guide Version 4.2. (2008). SAS Institute Inc., Cary, NC, USA

Scannell AGM, Kenneally PM, McCarthy D, Schwarz G, Arendt EK (2002) Optimisation of fermentation conditions for the production of fermented hams. Eur J Food Res 215:183-188

Scannell AGM, Kenneally PM, Arendt EK (2004) Contribution of starter cultures to the proteolytic process of a fermented non-dried whole muscle ham product. Int J Food Microbiol 93:219-230

Sørheim O, Ofstad R, Lea P (2004) Effect of carbon dioxide on yield, texture and microstructure of cooked ground beef. Meat Sci 67:231236

Stiles ME (1990) Modified atmosphere packaging of meat, poultry and their products. In: Stiles ME (ed) Modified atmosphere packaging of food. Ellis Horwood, New York, pp 118-147 